Great Clarity 



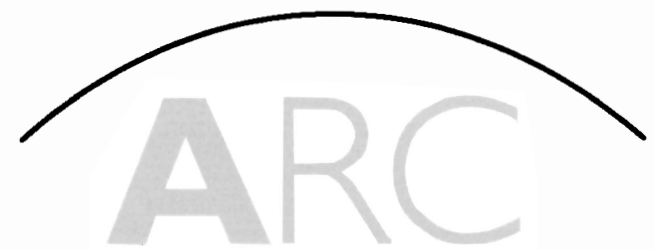

Asian Religions \& Cultures

Edited by

Carl Bielefeldt

Bernard Faure

Chinese Poetry and Prophecy: The Written Oracle in East Asia Michel Strickmann Edited by Bernard Faure 2005

Chinese Magical Medicine

Michel Strickmann

Edited by Bernard Faure 2002

Living Images: Japanese Buddhist Icons in Context Edited by Robert $\mathrm{H}$. Sharf and Elizabeth Horton Sharf 2001 

Fabrizio Pregadio

\section{Great Clarity}

Daoism and Alchemy

in Early Medieval China 


\section{Stanford University Press}

Stanford, California

(C) 2005 by the Board of Trustees of the Leland Stanford Junior University. All rights reserved.

No part of this book may be reproduced or transmitted in any form or by any means, electronic or mechanical, including photocopying and recording, or in any information storage or retrieval system without the prior written pemission of Stanford University Press.

Printed in the United States of America on acid-free, archival-quality paper

The information within this book is provided for academic and research purposes only. The Publisher accepts no responsibility for the way in which the information in this book is used and will not be held responsible for any damages arising from the use of any information featured in this book.

Library of Congress Cataloging-in-Publication Data

Pregadio, Fabrizio.

Great clarity : Daoism and alchemy in early medieval China / Fabrizio Pregadio.

p. cm. - (Asian religions and cultures)

Includes bibliographical references and index.

ISBN 0-8047-5 I 77-3 (cloth : alk. paper)

I. Daoism-China-History. 2. Alchemy-China-History. 3. China-Religion.

I. Title. II. Series: Asian religions \& cultures.

BLI920.P74 2005

$299.5^{\prime} 14^{\prime} 093 \mathrm{I}-\mathrm{dc} 22$

$200500298 \mathrm{I}$

Typeset by G\&S Book Services in Io/14.5 Sabon

Original Printing 2005 
To my parents 
